Espaço Aberto | Open Space

\title{
Percursos do Diabo e seus papéis nas igrejas neopentecostais
}

\section{Paths of the devil and his roles in neo-Pentecostal churches}

André Ricardo de Souza*

* Universidade Federal de São Carlos - São Carlos, SP, Brasil anrisouza@uol.com.br

https://orcid.org/0000-0001-5224-3117

Edin Sued Abumanssur ${ }^{* \star}$

** Pontifícia Universidade Católica de São Paulo - São Paulo, SP, Brasil edin@pucsp.br

https://orcid.org/0000-0001-7444-3582

Jorge Leite Júnior ${ }^{\star \star *}$

${ }^{* * \star}$ Universidade Federal de São Carlos - São Carlos, SP, Brasil

jcabelo@uol.com.br

https://orcid.org/0000-0001-6234-9169 


\title{
Resumo
}

O Diabo tem sido uma figura significativamente ascendente em grande quantidade de pessoas e igrejas. No Brasil, o segmento neopentecostal cresceu em boa medida combatendo as entidades do panteão afro-brasileiro. Em denominações dessa vertente é comum atribuir-se ao Diabo a influência negativa sobre pessoas, sendo também responsável pelo não pagamento de dízimos, o que evidencia o fato de tal figura exercer papel importante. Algumas igrejas costumam ainda demonizar organizações e indivíduos tipificados por elas como adversários nos campos: religioso, econômico, midiático e político, sendo que quando alguns de seus representantes parlamentares são fortemente acusados de corrupção, estes acabam também por sofrer diabolização seguida de descarte institucional. O caso mais eloquente e enfocado neste artigo é o da Igreja Universal do Reino de Deus (Iurd). Decorrente de sistemática pesquisa bibliográfica sobre o tema, o texto aborda sucintamente as diferentes fases históricas e faces do Diabo, no Ocidente e no Brasil em particular, enfocando o modo como ele é visto e representado contemporaneamente pelas denominações neopentecostais brasileiras, sobremaneira a Iurd, algo com implicações econômicas e políticas.

Palavras-chave: Diabo; cultura erudita e cultura popular; neopentecostalismo; Igreja Universal do Reino de Deus.

\begin{abstract}
The Devil has been a rising figure for most people and churches. In Brazil, neo-Pentecostalism grew in large part by combating the entities of the Afro-Brazilian pantheon. In the denominations of this branch, it is common to attribute to the Devil the negative influence on the people, being that he also is responsible for the non payment of tithes, evidencing their importance for these churches. They also demonize organizations and individuals who oppose them in the religious, economic, media, and political fields. When some of their representatives are accused of corruption, they are also diabolized and cut off from the institution. The Universal Church of the Kingdom of God (Iurd) is the most eloquent case dealt with in this article. Based on the systematic research of the literature on the subject, the text succinctly addresses the different phases and historical faces of the Devil in the West and particularly in Brazil and its economic and political implications, with attention focused on how it is viewed and represented contemporaneously by the Brazilian neo-Pentecostal denominations, especially the Iurd.
\end{abstract}

Keywords: Devil; erudite culture and popular culture; Neopentecostalism; Universal Church of the Kingdom of God. 


\section{Introdução}

O Diabo é uma figura mítica ou doutrinária cuja referência tem ao longo da história influenciado práticas de indivíduos e instituições, estando muito presente na literatura, nas artes plásticas e na dramaturgia. Tradicionalmente tido como personificação do mal, " "príncipe das trevas" ou "chefe dos demônios", ele segue provocando temor e culto, pois, se de um lado, o tradicional exorcismo católico se espraiou e popularizou-se em igrejas evangélicas, de outro, o intrigante satanismo, de alguma forma, se disseminou. Na formação das religiões afro-americanas, o Diabo foi sincretizado sobremaneira com o orixá iorubano Exu, interpretado como a divindade regente de entidades espirituais homônimas, também em versão feminina, chamada de Pombagira. Enquanto nos primeiros séculos do cristianismo, as religiões pagãs eram demonizadas, no período medieval, os indivíduos assim atingidos eram denominados hereges e, portanto, tornados vítimas de perseguição, tortura e extermínio. Posteriormente, a diabolização ocorreu sobre a religiosidade de origem indígena e, principalmente, africana.

Este artigo aborda diferentes fases históricas e facetas do Diabo, apontando a personificação dele em alguns grupos sociais ou indivíduos, ${ }^{2}$ algo que tem sido usado para perseguir e punir, com base no medo do "contágio do mal". Possuindo muitos nomes, essa figura milenar viveu mudanças de interpretação entre a cultura teológica erudita e a cultura popular, passando das formas de condenação para outras de pactuação. A parte final do texto enfoca o modo como o Diabo é visto e representado contemporaneamente nas denominações neopentecostais brasileiras, algo que tem relevantes implicações econômicas e políticas.

\section{O desenvolvimento do Diabo no mundo moderno}

O Diabo do cristianismo, como o conhecemos hoje em dia, tem data e local de nascimento. A ideia de um ser astuto e maligno, que tem como principal objetivo de sua existência provocar a perdição eterna do ser humano, e vive em

1 De origem grega, a palavra diabo significa "acusador".

2 Algumas revistas semanais de grande circulação nacional ainda estampam suas capas com tais indivíduos que exercem liderança política, fazendo acentuada alusão diabólica. 
eterna batalha contra as forças da bondade, inimigo do Deus cristão e quase tão poderoso quanto ele, foi desenvolvida entre os séculos XII e XIV na Europa ocidental, particularmente na França e na Inglaterra (Muchembled, 2001), rapidamente se espalhando pelo resto do continente (Nogueira, 2000).

Antes desse período, o Diabo era visto tanto pela cultura popular quanto por grande parte das autoridades religiosas medievais como um ser fracassado e estúpido. Impotente para desafiar Deus e inapto para ludibriar o ser humano, na Alta Idade Média o Demônio era para ser mais ridicularizado do que temido (Macedo, J., 2000). Com as mudanças sociais, políticas e econômicas que vão começar ocorrer a partir do século XI, como as Cruzadas e a abertura de novas rotas de comércio com o Oriente Médio e a Ásia, inicia-se também na Europa ocidental toda uma renovação intelectual e, consequentemente, político-religiosa.

Conforme Claude Kappler (1994), junto com as riquezas, chegam também à Europa relatos de entidades sobrenaturais maléficas e perigosas existentes no Oriente. Como o catolicismo enfrenta um período de crise de autoridade, tanto interna quanto externa - o Cisma do Oriente (século XI), a heresia dos cátaros (séculos XII-XIII) - tais narrativas religiosas influenciam diretamente uma nova forma de justificar a necessidade da Igreja Católica: ela iria proteger os humanos do Diabo, que, ao contrário do que se acreditava antes, não era parvo e cômico, mas sim maligno e destrutivo. Assim, do século XIV em diante, a figura de Satã e seus demônios só cresce em influência, poder e periculosidade. De serviçal, o Diabo passa a se tornar teológica e politicamente cada vez mais importante, forte e assustador, a ponto de, no início da modernidade, já ser um rival à altura do Deus cristão (Muchembled, 2001).

Por forte influência do neoplatonismo, entre as várias interpretações filosófico-religiosas que vão ordenando as bases do cristianismo durante sua fase inicial de estruturação doutrinária, está a ideia de Deus como algo eterno, fixo e de essência imutável (O'Grady, 1991). O Diabo então aparece como o oposto e a inversão de Deus, sendo inconstante, transitório, ligado à variedade e mudança das formas, nunca definitivo, completo ou perfeito. Deus revela-se nas ideias claras e aparências precisas, enquanto o Demônio associa-se aos conceitos dúbios e formas intermediárias (Francastel, 1973; Link, 1998; Muchembled, 2001).

A partir do século XIII, o Diabo forjado pelo cristianismo europeu começa a apresentar uma incrível variedade de imagens - mesmo com a predominância, 
cada vez maior, da figura do deus grego Pã como modelo para sua aparência ${ }^{3}$ (Link, 1998; Macedo, J., 2000; Muchembled, 2001; O'Grady, 1991). Segundo Luther Link (1998), isso se mostrou uma estratégia fundamental para a longevidade do medo e da crença nesse ser. Como Satã pode assumir diferentes formas, qualquer pessoa ou grupo pode personificá-lo: judeus, mulheres, homossexuais, negros, muçulmanos, comunistas, umbandistas, terroristas, criminosos e até mesmo animais ou objetos podem ser encarnações ou manifestações do Demônio, pois a variabilidade e mutabilidade de aparências (e nomes) é vista como um de seus atributos principais.

Outra característica sua é a mistura de reinos em um mesmo corpo. Humanos, animais e seres mágicos/divinos (pois acredita-se que o Diabo havia sido um anjo), unidos em uma mesma forma, resultam na imagem demoníaca. Assim, as infinitas combinações dentro desses reinos podem gerar novas e cada vez mais assustadoras versões desse ser (Kappler, 1994; Sáez, 1999): um cão com cabeça de serpente; um homem com cascos de bode; uma mulher sensual com rabo de gato; uma idosa grávida; uma criança com ambiguidade genital ou uma pessoa com alguma deformidade física. Nesse sentido, não apenas o maravilhoso ou extraordinário passam a evocar a marca de Satã, mas qualquer ser humano pode potencialmente apresentar algum sinal demoníaco em seu corpo que denuncie o comércio com o Diabo e o avanço de seu império (Kappler, 1994; Muchembled, 2001).

Esse ponto é extremamente importante, pois, dessa forma, todos podem se tornar um inimigo de Deus (uma vez que são vistos como cúmplices, intencionais ou não, de Satã). Assim, inicia-se toda uma estratégia política de acusação de desafetos que, no limite, levará não apenas à exclusão e punição dessas pessoas, mas também à morte física, como no caso da "caça às bruxas" ocorrida durante a Idade Moderna. É dentro dessa lógica delatória que podem ser pensadas as acusações de pactos e possessões demoníacas.

Ainda segundo Kappler (1994), a relação entre a mulher e o maligno vai se tornando cada vez mais forte a partir da Baixa Idade Média, a ponto de, junto com o Renascimento, surgir o equivalente feminino do Diabo que aterrorizará

3 A influência da imagem de Pã (O deus grego dos bosques e protetor dos rebanhos, que era representado como um homem barbudo com chifres, orelhas e pernas de bode) parece ser mais forte na Inglaterra e na França. Sáez (1999) mostra como ela vai chegar mais tarde na Espanha. 
o imaginário europeu e suas futuras colônias:4 a bruxa. "O diabo, a mulher e o monstro se encontram e passam a constituir, sozinhos ou aos pares, um corpo poderosíssimo" (Kappler, 1994, p. 349). Apesar de existirem muitos relatos de homens condenados por feitiçaria (Delumeau, 1989), essa campanha religiosa foi voltada especialmente às mulheres que, ao lado de devotos de outras religiões (judeus, muçulmanos) e culturas (como os povos nativos das Américas), encarnaram a figura diabólica de inimigas do cristianismo, inaugurando a longa série de feminicídios e genocídios da modernidade.

Conforme Foucault (2001), na França especificamente, mas também em grande parte da Europa, o processo de perseguição às bruxas e à feitiçaria teve duas fases características. Na primeira, que teve seu auge nos séculos XV e XVI, as perseguições ocorriam mais em zonas rurais, onde o cristianismo não era muito forte e ainda existiam resquícios de cultos e práticas de religiosidades pagãs antigas e locais. Nesse caso, as bruxas eram principalmente as más cristãs, as mulheres - comumente idosas - que guardavam o conhecimento prático para sobreviver à dura vida no campo, exercendo as técnicas de cura e os métodos de parto. A principal acusação feita contra elas era a de pacto com o Diabo.

Na segunda fase, nos séculos XVII e XVIII, o foco eram os centros mais urbanizados e próximos às instituições de poder e controle da Igreja, como os monastérios e conventos. Se antes a perseguição à bruxaria estava nas franjas e limites territoriais do cristianismo, agora ela se encontra no próprio coração dessa religião. $\mathrm{O}$ fenômeno maligno deixa de ser majoritariamente o pacto e passa a ser a possessão, onde novamente as mulheres eram o alvo preferencial. Ao contrário das feiticeiras, vistas como pouco ou quase nada cristãs, as possessas eram preferencialmente as devotas, muitas vezes fazendo parte da própria estrutura institucional dessa religião, como as freiras ou as madres superioras (Foucault, 2001).

O pacto e a possessão são dois lados de uma mesma moeda que denuncia interações ilícitas com o Demônio. Este é um ponto extremamente

4 O medo popular encarnado pela figura da bruxa e a violência como resposta a essa suposta ameaça não estão apenas na memória de uma narrativa histórica estrangeira e ultrapassada, mas na realidade contemporânea de muitos países que foram suas colônias, como o Brasil. Vide, por exemplo, o caso de Fabiane Maria de Jesus, linchada em 3 de maio de 2014, na cidade de Guarujá (SP), acusada de ser bruxa (Campanha, 2014). 
importante: o pacto com o Diabo e a possessão demoníaca são, antes de tudo, categorias de acusação. ${ }^{5}$

No pacto, o sujeito convoca o Demônio e faz uma barganha com ele. Não é o anjo caído que vai atrás da bruxa, mas ela quem o procura. Em troca de sua alma divina e imortal, a pessoa recebe o que a vida terrena reserva para poucos: bens materiais, prazeres da carne e, principalmente, poder sobre a própria vida e a de outros. Nesse tipo de comércio, está pressuposto que a pessoa livremente escolheu fazer um acordo com Satã e, dessa forma, optou intencionalmente pelo mal.

Assim, o pacto satânico evoca um dos conteúdos teológicos mais importantes do cristianismo: o livre-arbítrio e seus riscos, como a possibilidade de tirar seu destino das mãos da Providência e moldar seu próprio caminho, inclusive elegendo o que é proibido. Ora, o tema da liberdade é fundamental para a doutrina cristã e sua autoridade política: sem o pressuposto da liberdade, não se justifica a legitimidade da punição. Afinal, se a dor e o sofrimento existem no mundo ou, teologicamente falando, se o mal supremo existe, como ele pode se encaixar na narrativa religiosa de um deus único e exclusivamente bondoso? Conforme Weber (2007, p. 116):

$\mathrm{O}$ antiquíssimo problema da teodiceia enfrenta exatamente a questão de saber como pode dar-se que um poder, apresentado ao mesmo tempo como onipotente e bom, haja criado este mundo irracional, povoado de sofrimentos imerecidos, de injustiças não castigadas e de incorrigível estupidez. Ou esse poder é onipotente e bom, ou não o é, ou nossa vida é governada por princípios inteiramente diversos de recompensa e de sanção, princípios que só é possível interpretar por via metafísica, se é que não escapam inteiramente à nossa capacidade de compreensão.

5 Assim como a categoria de satanismo. Até metade do século $\mathrm{XX}$, alguém ser denunciado como satanista era dizer que essa pessoa cometia crimes dos mais diversos (assassinatos, danos contra propriedades, injúrias) justificados por uma doutrina de negação e ódio a Deus. Em 1966, Anton Szandor LaVey (pseudônimo de Howard Stanton Levey) funda em São Francisco, Estados Unidos, a Igreja de Satã, baseado nos princípios de Estado laico e liberdade religiosa. Essa igreja prega que Deus ou o Diabo são símbolos, não seres reais, e que seus devotos, como qualquer cidadão, devem obedecer às leis locais - ou seja, não devem cometer crimes. A partir de então, ser satanista (e praticar o satanismo) faz parte do esforço para se pertencer a uma categoria de identidade religiosa, apesar da visão conservadora até hoje ainda usar esse termo como forma de acusação e súplica de punição. 
Ou seja, ou esse Deus não é onipotente, ou ele não é unicamente bom. Para resolver essa questão tão teológica quanto política, o cristianismo desenvolveu a ideia de livre-arbítrio, na qual o mal seria não obra do Criador, mas consequência das escolhas humanas, segundo a interpretação de Santo Agostinho (1995). Se partirmos do princípio que o sujeito não pode escolher entre fazer o bem e o mal, não existe autoridade (terrena ou divina) para fundamentar o castigo, pois se a pessoa fez o errado mas não tinha outra opção, então não é correto puni-la afinal ela não poderia ter feito outra coisa (o certo). Esse é um dos elementos conceituais mais importantes do que depois virá a se desenvolver filosoficamente como o sujeito liberal burguês: sem o pressuposto da liberdade de escolha, não se justifica a punição daqueles que escolheram o proibido. Assim, acusação de pacto satânico é a denúncia de que alguém não está em conformidade com as doutrinas e nem obedecendo aos preceitos religiosos - ao mesmo tempo em que a própria ideia de pacto questiona os limites da autonomia do cristão.

Outro dado histórico importante sobre o pacto demoníaco é que, ainda conforme Foucault (2001), o período da caça às bruxas em que o foco esteve nessa barganha endiabrada foi justamente o Renascimento, quando o movimento humanista dotou os sujeitos de uma capacidade de agência infinitamente maior do que se aceitava até então. Nesse momento, a noção de pacto pressupunha não apenas uma troca sem a chance de arrependimento, mas também a constante oportunidade do ser humano de ludibriar o Demônio, driblando ao mesmo tempo as proibições de Deus e as condenações do Diabo.

Não é por acaso que surgiram nesse período as narrativas sobre o Dr. Fausto, ${ }^{6}$ ainda hoje um dos maiores mitos sobre as possibilidades de (des)acordo com forças desconhecidas, mostrando como havia narrativas em que a possiblidade de negociação era uma habilidade tanto humana quanto de entes sobrenaturais, e o Diabo popular ainda não estava tão poderoso e autoritário quanto prescreviam as autoridades eclesiásticas (Ferreira, 1992).

Do século XVII em diante, a partir do momento em que as possessões demoníacas passam a protagonizar as cenas de acusações religiosas, o Demônio

6 O personagem Fausto é um sábio que, tendo alcançado os limites da compreensão humana, faz um pacto com Mefistófeles, um demônio, oferecendo sua alma em troca de poder, prazeres e conhecimento dos segredos do universo. Sua estória surgiu na Alemanha durante o Renascimento. 
mostra-se como denunciado pelos teólogos: violento, intratável, traidor e enormemente poderoso. Com sua recente energia descomunal, o Demônio invade e se apossa dos corpos humanos. Não existe mais a troca estabelecida por um pacto; agora a devota não recebe nenhum benefício, mas apenas sofre abuso e violação física e espiritual.

A possessão é um fenômeno místico que se manifesta corporalmente, ganhando relevância no mesmo momento histórico em que o conhecimento científico começa a adquirir autonomia e vencer a batalha para se separar das interpretações religiosas e uma nova visão de corpo, cada vez mais materialista e naturalizada, ganha terreno nos debates filosóficos e políticos. O conflito entre a alma divina e a carne endemoniada da fiel dramatiza corporalmente os embates e divergências entre visões de mundo, práticas corporais e condutas sociais distintas.

O ato possessivo como o oposto do pacto revela a completa falta de controle ou agência sobre si. O livre-arbítrio é uma impossibilidade e a superioridade maligna se revela pelo grau de domínio que o Demônio tem sobre a existência da vítima. A solução para essa fragilidade foi o reforço da autoridade espiritual cristã através do ritual do exorcismo. Através dele, o padre ou pastor entra em combate direto com o Diabo, ressaltando a passividade do possuído: entre Cristo ou Satã, o controle de sua vida encontra-se fora de suas mãos. A acusação de possessão demoníaca reforça a crença na dependência de um perito externo e limita enormemente as possibilidades de autonomia e controle de si mesmo.

Apesar dessa separação histórica bem definida, na crença cotidiana de muitos devotos existia uma gradação entre esses dois extremos, o pacto e a possessão: o pacto podia surgir em decorrência de uma possessão prévia tanto quanto a possessão demoníaca poderia resultar de algum tipo de pacto com o Diabo (intencional ou não). O importante desses dois eventos é que eles ajudaram a reforçar uma visão teológico-política que vai manter sua influência até os dias de hoje, tanto no plano teológico quanto no político-institucional: o perigo dos comércios não autorizados e a necessidade de submissão a uma autoridade para dirigir a vida humana visando escapar dos crescentes e ocultos poderes demoníacos.

O Diabo, conforme cresce em poder, necessita cada vez mais de um local próprio de atuação, não apenas para localizá-lo em uma geografia teológica, mas também para circunscrever e delimitar sua cada vez mais ampla dominação 
espiritual. Por isso, o desenvolvimento dessa figura como a conhecemos hoje em dia foi concomitante ao desenvolvimento de seu reino: o inferno. Conforme Georges Minois (2005), apesar de o inferno cristão ser descrito de várias maneiras desde o começo da Alta Idade Média, ele só será plena e visualmente concebido entre os séculos XIII e XIV, estando uma de suas versões mais famosas na Divina comédia de Dante Alighieri, que vai unir antigos relatos populares (como "A visão de Túndalo"- século XII) com novos discursos eruditos sobre como seriam a morada do Demônio e os suplícios pós-morte dos pecadores.

É importante lembrar que para a mentalidade do medievo europeu, o Paraíso, o Inferno e o Purgatório - esse último também criado entre os séculos XII e XIII (Le Goff, 2009) - eram locais reais e concretos. Tanto as exultações do céu quanto as penitências do purgatório ou os tormentos infernais eram vistos como experiências físicas que ocorreriam em um território específico e palpável. Dessa forma, o Diabo ganha um reino próprio tão poderoso quanto o de Deus, tanto no plano material quanto no ético e espiritual.

Com a sistematização do inferno com uma geografia característica e regimento próprio, o cristianismo consegue dar uma possível solução ao problema teológico da justiça divina que vai repercutir até os dias de hoje: a fé no inferno é a confiança na existência de um lugar onde os maus serão castigados, pois se a lei humana não funciona nesse mundo, no além a justiça cósmica é implacável e garantida. Para a Europa cristã, a crença no inferno é tanto a ameaça da punição quanto a convicção de que existem terras potencialmente afeitas aos demônios - como as Américas, a partir do século XVI (Souza, L., 1993).

Ainda assim, o pobre-diabo da cultura popular europeia não será extinto, mas viajará nas esperanças e temores dos navegantes nos porões das caravelas e se adaptará aos trópicos dos países colonizados (Carvalho, 2004; Menezes, 1985; Sáez, 1999). Miserável entre os miseráveis, poderoso entre os poderosos, companheiro de infortúnios entre os deserdados da Terra e ganancioso entre os abastados do Céu, tanto os estratos mais pobres quanto as elites farão seus usos estratégicos do Demônio.

A cada nova leva de expansão tanto geográfica quanto teológica do cristianismo, a figura do Diabo a acompanha e aumenta em importância. Da mesma maneira, nos períodos de crise de poder e legitimidade dessa religião, Satanás é chamado para, através do medo que causa, reforçar a fé em Deus e a crença nas instituições cristãs (Nogueira, 2000). Nesse sentido, o uso do personagem 
demoníaco, desenvolvido a partir do início da Baixa Idade Média, será um instrumento político que, da(s) Igreja(s) ao Estado, continua em pleno funcionamento até os dias de hoje e no Brasil atual, conforme veremos mais à frente.

\section{Da cultura teológica erudita à popular brasileira}

Legião porque são muitos. ${ }^{7}$ Não apenas em quantidade, mas também em variedade. O Diabo é a síntese da ideia do mal. Para ele tende toda a possibilidade do mal. Todo o mal concentrado numa representação que pode ser descrita, circunscrita, restrita. O Diabo surge como solução antropológica para a constituição das sociedades. O Ocidente cristão sempre se houve com a personificação do mal na figura do Diabo. Ele é, talvez, o personagem mais explorado na literatura, na poesia, nas artes plásticas e, finalmente, no cinema. O mais retratado, 0 mais interpretado, o mais dissecado dos ícones do imaginário social cristão. Há abismos na figura do Diabo, feitos de fascínio e medo.

Trata-se de figura sagrada e, como tal, cercada de interditos e diferenciada das coisas profanas. Há, segundo Durkheim (2000, p. 452), "duas espécies de sagrado, um fasto, o outro nefasto". O Diabo é o sagrado nefasto, potência má e impura, razão de doenças, morte, malefícios, sofrimento, atentados à ordem social hegemônica. O divino e o diabólico são os dois polos, contrários e antagônicos, em torno dos quais gravita grande parte da vida religiosa.

O Diabo tem muitos nomes: Satanás, Belzebu, Moloque (dos amonitas), Camos ou Peor (dos moabitas), Baal (os machos), Ataró (as fêmeas), Astorete (Astarté entre os fenícios), Tamuz (do Líbano), Rimnon (da Síria), Osíris, Ísis, Órus (egípcios), Belial, Azazel, Mammon, Mulciber (Milton, [s.d.], p. 23ss). Ou ainda: O Arrenegado, o Cão, o Cramulhão, o Indivíduo, o Galhardo, o Pé-de-Pato, o Sujo, o Homem, o Tisnado, o Coxo, o Temba, o Azarape, o Coisa-Ruim, o Mafarro, o Pé-Preto, o Canho, o Duba-Dubá, o Rapaz, o Tristonho, o Não-sei-que-diga, O-que-nunca-se-ri, o Sem-Gracejos (Rosa, 1982, p. 33). Capeta, Tinhoso, Capiroto, Pé-de-Bode, Sete-Peles, Cabrunco, Guaxumão, Sujeito, Capa-Verde, Chifrudo, Beiçudo, Besta Fubana, Bicho-Preto, Difamado, Zarapelho, Ranheta,

7 Conforme o Evangelho de Marcos (5:9): “Legião é o meu nome porque somos muitos." 
Tição, Danado, Rabudo, Bute, Carocho, Mofento, Malino, Abdel, Astuto, Fute, Mefisto, Cujo, Mocho. O Diabo tem mais nomes que Deus, talvez porque tenha diversas funções.

Mudam os tempos, mudam os nomes, muda o sujeito. O Diabo evoluiu no transcorrer dos séculos e não é hoje o que já foi na Idade Média ou no início da modernidade e os seus diferentes nomes atestam essas mudanças. Ao compararmos os nomes que John Milton lhe atribui com aqueles presentes na cultura e no imaginário popular brasileiro, percebemos que por trás da diferença nominativa está também a diferença na forma como o Diabo se faz presente e interage com as pessoas. Na cultura popular, diferentemente do que ocorria por volta dos séculos XVI ou XVII, o Diabo é tratado com a mesma sem-cerimônia dedicada àqueles que foram destituídos da majestade e estranhamento, próprios dos seres investidos de poder e autoridade. Entre Belzebu e o Cramulhão há um rebaixamento no trato da coisa. Com esse mesmo rebaixamento o Diabo é tratado nos cultos pentecostais. É possível pensarmos, por outro lado, que a forma de tratamento das coisas sagradas esteja relacionada às posições de classe. $O$ campo erudito tenderia a um tratamento mais formal e distanciado, com um viés racionalizante, das coisas santas. O campo popular da religiosidade, se assumirmos como válida essa tese, desenvolve um comportamento mágico, mais incorporado às rotinas diárias e às lides da vida comum (Weber, 1999, p. 322).

Os limites entre o sagrado e o profano não são claros em nenhuma instância da vida. Experimentar o mundo dessa forma cindida pode ser próprio de sociedades arcaicas ou primitivas, como queria Durkheim (2000). O raciocínio pode, inclusive, ser muito claro nas camadas sociais mais intelectualizadas. Mas as coisas sagradas, por distintas que fossem, sempre habitaram, conviveram e interagiram com o mundo profano. Na cultura popular brasileira, o Diabo não se apresenta da mesma forma como o faz na cultura teológica erudita. Podemos arriscar dizer que não são sequer a mesma entidade.

Se compararmos o Ritual de exorcismo e outras súplicas (Conferência Nacional dos Bispos do Brasil, 2008), promulgado pela CNBB em 2004, com o imaginário sobre o Diabo expresso na literatura de cordel ou nas histórias que circulam nos meios populares, quer católicos ou pentecostais, veremos que se trata de discursos com poucos pontos de tangência.

A prática do exorcismo, nas camadas mais eruditas da Igreja Católica, é coisa rara e entre as denominações protestantes é quase inexistente. A igreja romana 
possui um rito formal para a prática do exorcismo e só deve ser usado em circunstâncias muito específicas, por determinados padres mediante a autorização dos bispos de suas dioceses. Diz o Ritual que a prática do exorcismo é uma licença concedida "pelo ordinário local", que em geral é o bispo diocesano (Conferência Nacional dos Bispos do Brasil, 2008, p. 17). A maneira como o exorcismo é visto e orientado por esse Ritual contrasta fortemente com a prática do exorcismo que vemos nas igrejas pentecostais. No catolicismo, segundo as orientações oficiais, a intervenção do sacerdote exorcista deve ser feita com a "máxima circunspecção e prudência". Exorta ainda que o sacerdote "não creia facilmente que alguém esteja possesso do demônio, pois pode tratar-se de outra doença, sobretudo psíquica" (Conferência Nacional dos Bispos do Brasil, 2008, p. 17).

Fica evidente, pela leitura do Ritual, que não é qualquer sacerdote que pode ou está habilitado a realizar os ritos de exorcismo. Pede-se dele sabedoria e discernimento para que tenha absoluta certeza de que os tormentos vividos pelo fiel, sejam, de fato, causados por possessão demoníaca. O Ritual é explícito sobre a necessária discrição no exercício desse ministério:

O exorcismo seja feito de forma que manifeste a fé da Igreja e ninguém possa considerá-lo uma ação mágica ou supersticiosa. Deve-se tomar cuidado para que não se transforme num espetáculo para os presentes. Enquanto se faz o exorcismo, de forma alguma se dê espaço a qualquer meio de comunicação social e até, antes de fazer o exorcismo e depois de feito, o exorcista e os presentes não divulguem a notícia, observando a necessária discrição. (Conferência Nacional dos Bispos do Brasil, 2008, p. 19).

Há duas coisas a se pensar sobre a maneira como a Igreja Católica lida com o Diabo. A primeira é a evidência do tratamento formal e solene com que os casos de possessão são tratados. Há seriedade e circunspecção diante dos casos de tormentos causados pelas forças demoníacas. A segunda coisa que se observa no Ritual é a necessidade de um sacerdote especialista e com múnus particular para praticar o exorcismo. Com isso, evita-se a banalização do ato e mantêm-se sob o controle do clero as vias de acesso ao universo das coisas sagradas.

O contraste com a forma pentecostal de lidar com o Demônio é evidente. O comportamento mais informal, corriqueiro e até jocoso entre os pentecostais, traz resultados positivos em submeter o Diabo e exercer ascendência e 
domínio sobre ele. Expor o Diabo ao ridículo é eficaz no controle dos casos de possessão. O caminho da Igreja Católica é oposto. A solenização do exorcismo traz acúmulo de capital simbólico para o sacerdote e, consequentemente, para a Igreja. Se entre os pentecostais a banalização do rito pode democratizar as relações com as coisas sagradas, entre os católicos os casos de possessão seriam oportunidades para demarcação de territórios afetos ao clero. Do lado pentecostal, o carisma do pastor entra em ação. Do lado católico, a afirmação da autoridade institucional.

No Ritual de exorcismo e outras súplicas, percebe-se que a ação do Diabo está circunscrita à vida espiritual e a principal consequência dos ataques demoníacos são as aflições espirituais e a incapacidade de resistir às tentações. Fundamentalmente, esse ritual busca trazer paz ao atormentado e restituir a alegria do convívio e da comunhão com a Igreja. Em outras palavras, o ritual do exorcismo praticado na Igreja Católica é um chamado à ordem. Em nenhum momento do Ritual o Diabo é pensado como algo ou alguém que possa agir se utilizando do corpo de uma pessoa. Ele age sobre o corpo, afligindo-o, atormentando-o, oprimindo-o, torturando-o. É para pôr limites ao sofrimento do fiel e reafirmar o lugar da Igreja na manutenção da ordem que o exorcismo é praticado.

Tomás de Aquino, no século XIII, de forma insuspeita, abriu as primeiras trilhas e plantou a primeira semente em solo cristão daquilo que veio a ser, 500 anos mais tarde, os fundamentos da sociedade e do Estado modernos. Aquino fez uma distinção entre o mundo espiritual e o mundo natural (cf. Costa, 2006, p. 37). Todos os eventos observáveis poderiam ser de ordem natural (a maioria dos eventos) ou de ordem espiritual. Estes últimos poderiam ser subdivididos em milagres (miracula) e maravilhas (miranda). O milagre seria a intervenção divina na ordem natural sem qualquer mediação. A maravilha seria também uma intervenção divina, mas dependente de causas secundárias e não implicaria a suspensão da Providência divina ordinária. A ação do Diabo só aconteceria no âmbito das maravilhas, porque os milagres seriam atribuição exclusiva de Deus. Essa proposição limitou a ação dos demônios, mas não impediu que eles continuassem a agir sobre as pessoas. Na verdade, os demônios se fizeram cada vez mais presentes no reino espiritual.

O interessante nessa questão não é apenas a restrição da ação do Diabo ao campo espiritual, mas, principalmente, a divisão criada entre mundo natural 
e mundo espiritual. Essa distinção evoluiu em direção àquela que conformou o pensamento e as motivações da ciência moderna e forneceu os fundamentos para a expansão da civilização europeia, a saber, a separação entre natureza e cultura.

O batismo é, de certa forma, considerado também um ritual de exorcismo. Alguns gestos e ritos são comuns aos dois momentos. São duas as fórmulas de exorcismo: uma depreciativa que é um pedido a Deus por proteção e graça e outra imperativa que é o esconjuro propriamente dito no qual, de forma clara e explícita, tanto o atormentado quanto a comunidade reunida declaram que renunciam ao Demônio e às suas obras. É a mesma declaração que o padre cobra da comunidade quando ministra o sacramento do batismo: "Renuncia a Satanás?" e todos respondem: "Renuncio" (Conferência Nacional dos Bispos do Brasil, 2008, p. 36).

Nos meios populares a situação é bem diferente. Se nos meios eruditos o Diabo é algo a ser evitado, em meio ao povo ele é enfrentado, desafiado e consorciado. Entre os violeiros são conhecidos diversos ritos de pactuação com o tinhoso. $\mathrm{O}$ bom violeiro, em algum momento, realizou um pacto com ele. É curioso que a possibilidade do pacto acontece também e da mesma forma com os músicos do blues americano. Lá essas estórias circulam entre os negros das comunidades mais pobres. Aqui, entre os caipiras tão pobres quanto. Dois mundos que se reconhecem na pobreza, na marginalidade e na falta da cultura letrada. Pessoas cujo virtuosismo nos seus respectivos instrumentos só poderia ser explicado por um suposto pacto feito com o Diabo. $O$ pacto seria o atalho para esse virtuosismo, porque o caminho divino é feito de muito estudo, dedicação e renúncia. $\mathrm{O}$ virtuosismo nos meios eruditos é proporcionado por um dom de Deus. Nos meios marginalizados, por um pacto demoníaco.

Os pactos podem ser realizados com entidades sagradas fastas ou nefastas. Não é apenas com o Diabo que se estabelecem acordos de interesse mútuo, mas também com os santos e mesmo com Deus. Diante do sagrado fasto, fazem-se promessas, firmam-se compromissos. Nessa situação busca-se o que falta, pede-se o retorno à normalidade. Diante de Deus ou dos santos não é lícito se desejar mais do que a vida aprouve dar. Fundamentalmente, a alma que se achega a Deus reconhece o seu lugar e seu papel neste mundo, confiante de que Deus em sua justiça determinou que esse seria o seu quinhão de dor e 
alegria. É essa consciência que dá autoridade à alma penitente de estabelecer um compromisso cujo destino e interesse é o retorno à regularidade da vida cotidiana.

Com o sagrado nefasto a coisa é diferente. Para o Diabo se pede o excesso, se deseja o que não tem e o que não lhe foi dado ter: riqueza, beleza, glória ou até o amor interdito. A alma que se aproxima do Diabo não está contrita e penitente, mas, ao contrário, está inconformada e insatisfeita, incontida e transbordante.

O Diabo é figura das mais retratadas na literatura de cordel e já foi objeto de vários estudos (Maior, 1975; Pontes, 1972; Santa Cruz, 1963). Na cultura e no imaginário populares, o Diabo é um ser com o qual se pode pactuar. Ele é passível de ser enganado, ludibriado. A literatura de cordel é rica em exemplos de situações em que a pessoa vende sua alma e depois a recupera através de subterfúgios repletos de malandragem. O Diabo popular é figura ambígua que transita entre a astúcia e a ingenuidade. Às vezes, é o que pune a perversão, outras vezes ele a premia. Às vezes tolo, às vezes sagaz. Em muitas ocasiões, ele é posto a serviço dos interesses mais mundanos como riqueza, fama e glória. Mas também, em contraste com sua ação e suas razões, firmam-se valores morais como a laboriosidade, a castidade para as mulheres, a fidelidade, a atenção reverente aos sacramentos, a coragem.

Os meios pentecostais herdaram essa forma popular de se haver com o Cão. Não em relação ao estabelecimento de pactos ou consórcios para a obtenção de favores, mas sim em relação ao rebaixamento na forma de tratar o Capiroto, sem qualquer deferência solene, sem sustos, sem medos, sem arrepios. Esse é o Diabo tratável, manipulável, administrável. O mal sob o controle da palavra e da autoridade do pastor. O mal compreensível, gerenciável e aceitável. O mal possível e passível de ser enquadrado, lidado e trabalhado. $\mathrm{O}$ mal que permite continuar vivendo.

\section{Papéis do Diabo na Igreja Universal}

O desenvolvimento do neopentecostalismo teve um grande impacto no cenário religioso brasileiro, também com significativas consequências econômicas e políticas. As denominações dessa vertente estão entre as que mais crescem e 
geram controvérsias. ${ }^{8}$ Elas se caracterizam pela adoção da Teologia da Prosperidade, que tem como essência a ideia básica de que Jesus Cristo já redimiu a humanidade, de modo que todo seguidor tem o legítimo direito a riqueza, saúde e sucesso no mundo hoje, em vez de apenas no além. Se tal êxito não ocorre é porque a pessoa supostamente está em falta com Deus e entregue às ações do Diabo. Para reverter tal situação o adepto da igreja deve fazer a ela doações financeiras e materiais, contribuindo então, concretamente, com o trabalho de evangelização em execução. Quanto maiores são as ofertas mais “direito" tem a pessoa de "exigir" de Deus o cumprimento de sua parte do acordo, ou "contrato de fé". Com base em tal crença e através de testemunhos de pessoas que se afirmam bem-sucedidas, são realizados eventos e campanhas - chamados sobremaneira de descarregos, correntes e desafios - em que os fiéis são praticamente constrangidos a contribuir com a causa apresentada pela instituição religiosa, seja ela a construção de um templo, a aquisição de uma emissora de rádio, de televisão ou o que for. Se não fazem tal contribuição isso costuma ser atribuído à influência do Diabo (Campos, 1997; Mariano, 1999; Mariz, 2000).

Mas antes dessa vertente, o pentecostalismo de cura divina, sobretudo através do falecido pastor David Miranda com sua igreja Deus é Amor (de 1962), já apontava como fator crucial no alívio das doenças a luta contra o oponente divino ${ }^{9}$ identificado com as entidades espirituais do candomblé e da umbanda (Rolim, 1990). Ocorre que as denominações neopentecostais levaram ao extremo a ênfase na figura do Diabo, tendo havido para elas um fundamental agente intermediário: o pastor canadense Walter Robert McAlister, iniciador da Igreja Pentecostal Nova Vida (1960), da qual saíram os respectivos fundadores da Iurd e da IGD: Edir Macedo Bezerra e Romildo Ribeiro Soares, conhecido como R. R. Soares. Em 1968, McAlister publicou o livro Mãe-de-santo, que relata detalhes de iniciação de uma sacerdotisa baiana do candomblé que "finalmente descobriu não mais pertencer sua alma ao diabo, pois o sangue de Jesus Cristo passou a ser em sua vida mais forte e poderoso que quaisquer oferendas"

8 Atrás em termos de tamanho e crescimento da Assembleia de Deus, atualmente, as principais igrejas neopentecostais são: Universal do Reino de Deus (Iurd, fundada em 1977), Internacional da Graça de Deus (IGD, em 1980), Sara Nossa Terra (1992) e Mundial do Poder de Deus (IMPD, 1998).

9 No presente, quem se destaca por tal característica é o pastor Valdemiro Santiago de Oliveira, fundador e líder da IMPD. 
(McAlister, 1983, p. 5). Vinte anos depois daquela obra inaugural desse tipo no meio evangélico, Edir Macedo (2002) publicou Orixás, caboclos e guias: deuses ou demônios. ${ }^{10}$ Baseando-se também em sua própria trajetória de ex-umbandista, Macedo aponta de modo virulento as entidades do candomblé, da umbanda e do espiritismo como diabólicas. Com formato parecido a Mãe-de-santo, esse livro é repleto de relatos e ilustrações de rituais das religiões afro-brasileiras, contendo legendas interpretativas com destaque para fotos com sangue sacrificial, tridente e algumas notícias de assassinato envolvendo os adeptos de tais cultos (Silva, 2007b). Em 2005, uma juíza federal da Bahia determinou a suspensão da circulação da obra, mas no ano seguinte o Tribunal Regional Federal 1, de Brasília, liberou sua venda.

Naquele livro, o líder iurdiano afirma que todo o mal no mundo advém do Diabo, sendo traduzido sobremaneira em: doença, desemprego, baixa remuneração, vícios e desavenças familiares. Daí o combate permanente às diversas "feições diabólicas": exus, caboclos, pretos velhos, orixás, guias e espíritos, amaldiçoando o universo religioso rotulado de: macumba, feitiçaria, magia negra e demonismo. Com isso a igreja não só reconhece como real a experiência das religiões de transe, mas também assimila algumas de suas crenças, através da chave diabolizante (Almeida, 1996; Mariano, 2003, p. 30; Silva, 2007a, p. 228). Mais que nas demais denominações neopentecostais, há na Iurd uma explícita e permanente guerra espiritual contra o mal satânico localizado em outras tradições religiosas, principalmente nos cultos afro-brasileiros (Almeida, 2009; Mariano, 2003; Silva, 2007a).

O combate neopentecostal, sobretudo iurdiano, ao Diabo acarreta perseguições e ataques aos adeptos das religiões afro-brasileiras, nas formas de: invasões e depredações de terreiros, insultos e até agressões físicas ao povo de santo (Silva, 2007b). As denominações do pentecostalismo clássico e de cura divina se restringiam antes ao âmbito discursivo, sem alcançar tal patamar de violência. Ao longo da trajetória da Iurd, buscou-se efetivamente a eliminação de grupos de culto afro-brasileiro e a conversão de seus adeptos (Almeida, 2009, p. 74; Silva, 2007a).

Interessante notar o fato de sintomas daquilo que espíritas chamam de "obsessão espiritual" (Lewgoy, 2003) - insônia, intenso nervosismo, constantes

10 Nessa literatura, destaca-se também Espiritismo: a magia do engano, publicado por R. R. Soares (1984). 
dores de cabeça, desmaios, medo, desejo de suicídio, depressão, visões de vulto e audição de vozes - serem apontados como expressão da ação diabólica, fazendo com que a vítima necessite de uma "libertação", cabendo este "trabalho especial" à Iurd (Macedo, E., 2002, p. 9).

Sendo a suposta influência do Diabo o principal motivo apontado por dirigentes, pastores e obreiros da Iurd para a não contribuição financeira das pessoas que acorrem aos templos, cabe tratarmos um pouco da destinação de tal arrecadação. O maior feito economicamente empreendedor no âmbito da Iurd foi a compra em 1989, no valor de 45 milhões de dólares, das três principais emissoras e os direitos sobre a Rede Record de Rádio e Televisão, por Edir Macedo. Nos últimos anos, ele incorporou à rede as ações antes pertencentes a outros bispos, o que o tornou proprietário de um patrimônio estimado em dois bilhões de reais (Lobato, 2005; Souza, A., 2011).

Essa pujança econômica, aplicada em uma ampla rede de comunicação que vai bem além daquela emissora televisiva - e associada ao discurso persecutório em nome da "liberdade religiosa", tem também relevantes implicações políticas (Freston, 1999, p. 155; Giumbelli, 2002, p. 346-348). Depois de eleger seu primeiro deputado federal em 1986, a Iurd passou a três federais em 1990, dobrando o número nas eleições seguintes. Naquele pleito, um dos destaques foi Paulo de Velasco, então importante liderança da igreja, assim como apresentador de programa popular da TV Record (Campos, 2006, p. 60-75; Conrado, 2000; Oro, 2006, p. 119). Na trajetória da Iurd, enquanto algumas lideranças foram promovidas, ascendendo politicamente, ${ }^{11}$ outras foram, muitas vezes, demonizadas e, deliberadamente, extirpadas. Os parlamentares que perdem apoio da Iurd acabam ficando sem chances eleitorais. Alguns casos deixam esse fato bem evidente. Magaly Machado, eleita deputada estadual em 1994 e 1998, a despeito de um reconhecido trabalho social em favelas do Rio de Janeiro foi descartada e deixou de ser reeleita em 2002. Naquele pleito o mesmo ocorreu com o televisivo Paulo de Velasco (Campos, 2006, p. 59; Fonseca, 2002, p. 142-156). Tais casos evidenciam o pertencimento do capital político-eleitoral não ao indivíduo, mas sim à igreja (Oro, 2006).

11 Principalmente Marcelo Crivella, sobrinho de Edir Macedo, que de bispo e cantor gospel se tornou senador pelo Rio de Janeiro, ministro da Pesca no governo Dilma Rousseff e foi eleito prefeito do Rio em 2016. 
Mas o maior exemplo de descarte político feito pela Iurd, diabolizando o indivíduo - envolto em acusações judiciais - e preservando a instituição é o de Carlos Rodrigues. Sendo um dos fundadores iurdianos, Rodrigues propôs a Edir Macedo, ainda em 1982, o lançamento de candidatos a vereador no Rio, tornando-se com isso coordenador político da igreja. No período das eleições, ele se afastaria das funções pastorais para se dedicar exclusivamente às campanhas dos candidatos apoiados pela denominação. Carlos Rodrigues viria exercer papel importante também na implantação da Iurd na Argentina, Portugal, Espanha, Angola, África do Sul e Moçambique. No Brasil, sua função de cérebro político iurdiano ganhou visibilidade quando ele passou ter um escritório de "assessoria parlamentar evangélica”, em Brasília, no ano de 1996 (Fonseca, 2002, p. 139-141).

O então bispo Rodrigues decidiu se candidatar e, em 1998, foi eleito deputado federal, sendo reconduzido ao cargo como o mais votado entre os dez evangélicos eleitos, bem como o quarto deputado que mais recebeu votos no estado do Rio de Janeiro. Além de se eleger com muitos votos e se tornar o vice-presidente do Partido Liberal, Rodrigues foi o articulador do bloco evangélico pró-Lula, angariando adesões desse segmento religioso ao candidato à presidência da República, que havia sido sempre rejeitado pelos pentecostais. Sob a anuência de Macedo, Carlos Rodrigues dirigiu as candidaturas e estratégias eleitorais da Iurd por quase duas décadas, de 1982 a 2004, bem como coordenou as ações políticas dos parlamentares ligados à igreja entre 1999 e 2005, quando foi abatido por um vendaval de escândalos e então diabolizado pela instituição religiosa que ajudou a desenvolver.

Em maio de 2005, o e então deputado federal Roberto Jefferson denunciou um grande esquema de compra de votos de parlamentares e desvio de verbas públicas que ficou conhecido como "mensalão". Um dos principais acusados era Rodrigues..$^{12}$ Não bastasse isso, ele foi acusado, em 2006, pela Polícia Federal de ser um dos maiores beneficiados de um esquema de superfaturamento na compra de ambulâncias em troca de emendas parlamentares, algo que ficou conhecido como "máfia das sanguessugas". Neste último escândalo, chamou

12 Ele viria a responder processo com mais 39 indiciados junto ao Supremo Tribunal Federal (STF). Em 1998 - em meio às investigações sobre o envio de dinheiro de líderes iurdianos a paraísos fiscais - Carlos Rodrigues já havia sido acusado pela Receita Federal de acréscimo de $15.000 \%$ em seu patrimônio, algo notoriamente incompatível com seus rendimentos pessoais (Fonseca, 2003, p. 180). 
atenção o protagonismo e a presença maciça de parlamentares evangélicos. Nada menos que 14 dos 16 (87\%) deputados federais da Iurd estavam envolvidos. E isso teve repercussão nas eleições de 2006. Procurando amenizar os danos à sua reputação, a igreja retirou o apoio aos parlamentares acusados. O número de deputados federais ligados a ela caiu dois terços, chegando a cinco. Carlos Rodrigues, por sua vez, deixou de ser bispo e acabou expulso, tanto da Iurd quanto de seu partido. Com isso, ele não só se juntou ao rol de lideranças eclesiásticas e políticas satanizadas e descartadas pela denominação de Macedo, mas se tornou a maior delas.

Como se pode ver, o Diabo cumpre nas igrejas neopentecostais, principalmente na Iurd, um relevante papel político e também econômico. Sempre que um parlamentar se vê bastante envolvido em controvérsias e acusações judiciais é demonizado e pragmaticamente extirpado em prol da preservação institucional. Associado a entidades das religiões mediúnicas, culpabilizado pelos escândalos políticos e também pela ausência ou redução das contribuições financeiras, o Diabo acaba sendo, na verdade, um grande aliado das denominações neopentecostais, principalmente a Iurd, que é vista por parte de seus opositores no campo religioso como uma "diabólica" igreja.

\section{Considerações finais}

O Diabo se tornou uma poderosa figura no imaginário coletivo na Europa medieval e moderna, servindo à perseguição crescente de grupos sociais estigmatizados e marginalizados. Indivíduos demonizados foram reprimidos, encarcerados, torturados e até executados, supostamente passando a habitar o inferno junto com Satanás. Nos momentos de crise de poder e de legitimidade institucional, o Diabo se tornou cada vez mais invocado, suscitando medo e também grande ofensiva às pessoas a ele identificadas.

Já com muitos nomes e diferentes feições, o "Príncipe das Trevas" chegou à modernidade, tornando-se um grande personagem da literatura, da música, das artes plásticas e da dramaturgia, contribuindo fortemente para a movimentação de um grande montante financeiro. Considerado como a potência má, responsável por desequilíbrios individuais e sociais, infortúnios, malefícios, doenças e morte, o Diabo, gradativamente, adquiriu outra conotação na 
cultura popular, passando a não ser apenas repelido e evitado, mas também desafiado e consorciado. No meio pentecostal brasileiro, ele veio a ser tratado com proximidade, porém como alguém que deve ser publicamente atacado e afastado dos indivíduos mediante a pregação incisiva e dramática dos pastores.

A tradicional prática exorcista ganhou força ímpar na vertente religiosa iniciada no final da década de 1970, chamada neopentecostalismo (Mariano, 1999). Vale frisar que enquanto o exorcismo católico é restrito a alguns especialistas e não exposto publicamente, o evangélico, sobretudo neopentecostal, é extremamente popularizado e publicizado. Se o êxito em termos de saúde, vida econômica e afetiva, prometido pela Teologia da Prosperidade, não ocorre na vida das pessoas que frequentam as denominações neopentecostais é porque o Diabo, supostamente, está agindo sobre elas, sobremaneira inibindo o cumprimento do dever do dízimo e de demais doações financeiras demandadas pelas igrejas. A Iurd é destaque nesse quesito e também em outros, tal como o combate incessante a Satanás, personificado em orixás e entidades espirituais das religiões afro-brasileiras e do espiritismo. Antes apenas verbal, o ataque aos chamados filhos de santo e suas unidades de culto veio a se tornar ostensivo e até violento. Parlamentares iurdianos envolvidos em escândalos de corrupção foram pragmaticamente demonizados e, portanto, extirpados dessa igreja, sendo o ex-bispo Carlos Rodrigues o maior exemplo. Com isso, atribui-se o mal diabólico aos indivíduos, preservando-se a instituição. O Diabo acaba sendo um estratégico aliado econômico e também político das denominações neopentecostais, sobremaneira a Iurd.

Aquele ser temível do mundo antigo e medieval, que foi depois simbolicamente mobilizado na perseguição a grupos sociais como: judeus, ciganos, mulheres, homossexuais, negros, comunistas e muçulmanos, prossegue cumprindo tal papel político. Além disso, estimula grande movimentação financeira, seja pelo poder de fascínio e atração, seja pelo temor de sua ação, levando fiéis a contribuir com uma igreja que tem no nome o vínculo ao Reino de Deus, mas é vista por parte de seus adversários como algo a serviço do reino diabólico. O Diabo segue como protagonista de uma estratégica instrumentalização do medo que tem as faces: religiosa, política e econômica. 


\section{Referências}

ALMEIDA, R. de. A universalização do Reino de Deus. 1996. Dissertação (Mestrado em Antropologia Social) - Instituto de Filosofia e Ciências Humanas, Universidade Estadual de Campinas, Campinas, 1996.

ALMEIDA, R. de. A Igreja Universal e seus demônios: um estudo etnográfico. São Paulo: Terceiro Nome: Fapesp, 2009.

CAMPANHA, D. Família de mulher linchada em Guarujá temia boatos sobre 'bruxa'. Folha de S. Paulo, 11 maio 2014. Disponível em: http://www1.folha.uol.com.br/ cotidiano/2014/05/1452689-familia-de-mulher-linchada-em-guaruja-temia-boatos-sobre-bruxa.shtml. Acesso em: 30 jan. 2018.

CAMPOS, L. S. Teatro, templo e mercado: organização e marketing de um empreendimento neopentecostal. Petrópolis: Vozes; São Paulo: Simpósio Editora: Umesp, 1997.

CAMPOS, L. S. De políticos evangélicos a políticos de Cristo: uma análise do comportamento político de protestantes históricos e pentecostais no Brasil. In: BURITY, J.; ORO, A. P. (org.). Os votos de Deus: evangélicos, política e eleições no Brasil. Recife: FJN: Massangana, 2006. p. 59-107.

CARVALHO, L. G. de. O Diabo e o riso na cultura popular. Enfoques: Revista Eletrônica dos Alunos do PPGSA da UFRJ, v. 3, n. 1, mar. 2004.

CONFERENCIA NACIONAL DOS BISPOS DO BRASIL. Ritual de exorcismo e outras súplicas. São Paulo: Paulus, 2008.

CONRADO, F. C. Cidadãos do Reino de Deus: representações, práticas e estratégias eleitorais: um estudo da Folha Universal nas eleições de 1998. 2000. Dissertação (Mestrado em Sociologia e Antropologia) - Instituto de Filosofia e Ciências Sociais, Universidade Federal do Rio de Janeiro, Rio de Janeiro, 2000.

COSTA, E. F. Tratado dos demônios em Santo Tomás de Aquino. Ágora Filosófica, ano 6, n. 1, p. 23-48, jan./jun. 2006.

DELUMEAU, J. Os agentes de Satã III: a mulher. In: DELUMEAU, J. História do medo no Ocidente. São Paulo: Companhia das Letras, 1989. p. 310-349.

DURKHEIM, E. As formas elementares da vida religiosa. São Paulo: Martins Fontes, 2000.

FERREIRA, G. P. Fausto no horizonte. São Paulo: Hucitec, 1992. 
FONSECA, A. B. C. Secularização, pluralismo religioso e democracia no Brasil: um estudo sobre a participação dos principais atores evangélicos na política (1998-2001). 2002. Tese (Doutorado em Sociologia) - Faculdade de Filosofia, Letras e Ciências Humanas, Universidade de São Paulo, São Paulo, 2002.

FONSECA, A. B. C. Evangélicos e mídia no Brasil. Bragança Paulista: Edusf; Curitiba: Faculdade São Boaventura, 2003.

FOUCAULT, M. Aula de 26 de fevereiro de 1975. In: FOUCAULT, M. Os anormais. São Paulo: Martins Fontes, 2001. p. 255-292.

FRANCASTEL, P. Encenação e consciência: o diabo na rua no fim da Idade Média. In: FRANCASTEL, P. A realidade figurativa. São Paulo: Perspectiva, 1973. p. 351-370.

FRESTON, P. Protestantes e políticas no Brasil: da Constituinte ao impeachment. 1999. Tese (Doutorado em Ciências Sociais) - Instituto de Filosofia e Ciências Humanas, Universidade Estadual de Campinas, Campinas, 1999.

GIUMBELLI, E. O fim da religião: dilemas da liberdade religiosa no Brasil e na França. São Paulo: Attar, 2002.

KAPPLER, C. Monstros, demônios e encantamentos no fim da Idade Média. São Paulo: Martins Fontes, 1994.

LE GOFF, J. Heróis e maravilhas da Idade Média. Petrópolis: Vozes, 2009.

LEWGOY, B. O mal à moda espírita: as estruturas narrativas da desobsessão. Debates do NER, ano 4, n. 4, p. 91-108, 2003.

LINK, L. A aparência do diabo. In: LINK, L. O diabo: a máscara sem rosto. São Paulo: Companhia das Letras, 1998. p. 43-93.

LOBATO, E. Instinto de repórter. São Paulo: Publifolha, 2005.

MACEDO, E. Orixás, caboclos e guias: deuses ou demônios?. 15. ed. Rio de Janeiro: Universal Produções, 2002.

MACEDO, J. R. Riso, cultura e sociedade na Idade Média. Porto Alegre: Ed. UFRGS; São Paulo: Unesp, 2000.

MAIOR, M. S. Território da danação: o diabo na cultura popular do Nordeste. Rio de Janeiro: Livraria São José, 1975.

MARIANO, R. A Teologia da Prosperidade. In: MARIANO, R. Neopentecostais: sociologia do novo pentecostalismo no Brasil. São Paulo: Loyola, 1999. p. 147-186.

MARIANO, R. Guerra espiritual: o protagonismo do diabo nos cultos neopentecostais. Debates do NER, ano 4, n. 4, 2003, p. 21-34. 
MARIZ, C. O demônio e os pentecostais no Brasil. In: CIPRIANI, R.; ELETA, P.; NESTI, A. (org.). Identidade e mudança na religiosidade latino-americana. Petrópolis: Vozes, 2000. p. 251-264.

McALISTER, R. Mãe-de-santo. 4. ed. Rio de Janeiro: Carisma, 1983.

MENEZES, E. D. B. de. A cotidianidade do demônio na cultura popular. Religião e Sociedade, v. 2, n. 12, p. 92-130, 1985.

MILTON, J. O paraíso perdido. Rio de Janeiro: Ediouro, [s.d.].

MINOIS, G. Historia de los infiernos. Barcelona: Paidós, 2005.

MUCHEMBLED, R. Uma história do diabo. Rio de Janeiro: Bom Texto, 2001.

NOGUEIRA, C. R. F. O diabo no imaginário cristão. Bauru: Edusc, 2000.

O'GRADY, J. A aparência do diabo e a morada do inferno. In: O'GRADY, J. Satã o príncipe das trevas. São Paulo: Mercuryo, 1991. p. 55-66.

ORO, A. P. A Igreja Universal e a política. In: BURITY, J.; ORO, A. P. (org.). Os votos de Deus: evangélicos, política e eleições no Brasil. Recife: FJN: Massangana, 2006. p. 135-146.

PONTES, M. A presença demoníaca na poesia popular do Nordeste. Revista Brasileira de Folclore, Rio de Janeiro, ano 12, n. 34, p. 261-283, set./dez. 1972.

ROLIM, F. C. Igreja Pentecostal Deus é Amor. Cadernos do ISER, n. 23, p. 59-63, 1990.

ROSA, G. Grande sertão: veredas. 15. ed. Rio de Janeiro: José Olympio, 1982.

SÁEZ, O. C. Deus e o diabo em terras católicas (Brasil - Espanha). Taubaté: GEIC/Núcleo Interdisciplinar de Pesquisas de Práxis Contemporâneas, 1999.

SANTA CRUZ, L. O diabo na literatura de cordel. Cadernos Brasileiros, Rio de Janeiro, ano 5, n. 5, p. 3-14, set./out. 1963.

SANTO AGOSTINHO. O livre-arbitro. São Paulo: Paulus, 1995.

SILVA, V. G. da. Intolerância religiosa: impactos do neopentecostalismo no campo religioso afro-brasileiro. São Paulo: Edusp, 2007a.

SILVA, V. G. da. Neopentecostalismo e religiões afro-brasileiras: significados do ataque aos símbolos da herança religiosa africana no Brasil contemporâneo. Mana, Rio de Janeiro, v. 13, n. 1, p. 207-236, 2007b.

SOARES, R. R. Espiritismo: a magia do engano. Rio de Janeiro: Graça Editorial, 1984.

SOUZA, A. R. de. O empreendedorismo neopentecostal no Brasil. Ciencias Sociales y Religión, v. 13, p. 13-34, 2011. 
SOUZA, L. de M. e. Inferno atlântico: demonologia e colonização. São Paulo: Companhia das Letras, 1993.

WEBER, M. Economia e sociedade. Brasília: UnB, 1999.

WEBER, M. A política como vocação. In: WEBER, M. Ciência e política: duas vocações. São Paulo: Cultrix, 2007. p. 17-52.

Recebido: 31/01/2018 Aceito: 29/11/2018 | Received:1/31/2018 Accepted:11/29/2018 